\title{
IMMOBILISASI NANOPARTIKEL ZnO PADA KAIN ATAP KAPAS DAN EVALUASI KETAHANANNYA TERHADAP ULTRAVIOLET
}

\author{
IMMOBILIZATION OF ZnO NANOPARTICLES ON COTTON ROOF FABRIC \\ AND EVALUATION OF ITS DURABILITY AGAINST ULTRAVIOLET
}

\author{
Doni Sugiyana, Wulan Septiani, Agus Surya Mulyawan, Tatang Wahyudi
}

Balai Besar Tekstil, Jalan Jenderal Ahmad Yani No. 390 Bandung

E-mail: texirdti@bdg.centrin.net.id

Tanggal diterima: 30 Maret 2017, direvisi: 4 Oktober 2017, disetujui terbit: 2 November 2017

\begin{abstract}
ABSTRAK
Penggunaan nanopartikel pada material tekstil telah menjadi salah satu metode yang efektif dalam tujuan untuk menghasilkan kain dengan ketahanan yang baik terhadap ultraviolet/UV. Dalam penelitian ini telah dilakukan immobilisasi nanopartikel ZnO pada kain atap kapas dan evaluasi ketahanan kain terhadap irradiasi ultraviolet. Studi ini bertujuan untuk mengembangkan metode preparasi larutan nanopartikel ZnO dan metode immobilisasinya pada kain atap kapas. Metodologi penelitian meliputi preparasi larutan nanopartikel ZnO dengan optimalisasi konsentrasi binder-stabilizer-nanopartikel $\mathrm{ZnO}$ dan immobilisasi nanopartikel pada kain kapas dengan metode pad-dry-cure. Evaluasi dan pengujian dilakukan terhadap stabilitas larutan nanopartikel, ketahanan perlekatan nanopartikel pada kain dan kekuatan tarik serta mulur kain setelah irradiasi UV. Larutan nanopartikel ZnO menunjukkan stabilitas cukup baik pada penggunaan konsentrasi binder-stabilizer PVA-nanopartikel ZnO sebesar 5\% - 10\% - 5\%. Evaluasi perlekatan nanopartikel melalui metode uji siram hujan menunjukkan immobilisasi yang baik dengan penggunaan konsentrasi binder akrilat 5\%. Setelah irradiasi UV selama 5 jam, penurunan kekuatan tarik pada kain mengandung nanopartikel $\mathrm{ZnO}$ masing-masing hanya sebesar 1,4\% dan 1,7\% pada arah lusi dan pakan, lebih rendah dibandingkan kain tanpa nanopartikel $\mathrm{ZnO}$ dengan penurunan arah lusi dan pakan masing-masing sebesar 24,0\% dan $24,9 \%$ pada arah lusi dan pakan.
\end{abstract}

Kata kunci: binder, kain kapas, nanopartikel ZnO, stabilizer, ultraviolet.

\begin{abstract}
The utilization of nanoparticles to textile materials has been the one of effective methods aimed at producing fabrics with high durability against ultraviolet/UV. Immobilization of $\mathrm{ZnO}$ nanoparticles onto cotton roof fabric and evaluation of its durability against ultraviolet irradiation were carried out in this research. The aims are to develop the preparation method of $\mathrm{ZnO}$ nanoparticles and its immobilization method onto cotton roof fabric. Research methods including preparation of $\mathrm{ZnO}$ nanoparticles with optimization of binder-stabilizer-nanoparticles concentration, and immobilization of nanoparticles onto cotton fabric using pad-dry-cure method. Evaluation and testing have been done upon nanoparticles suspension stability, durability of nanoparticles attachment on fabric and tensile strength and creep of fabric after UV irradiation. ZnO nanoparticles suspension shows good stability at utilization of binder-stabilizer-nanoparticles concentration in 5\%-10\%-5\%. Nanoparticle attachment evaluation through rain shower test method shows good immobilization at utilization of 5\% acrylate binder. After 5 hrs of UV irradiation, reduction of tensile strength in fabric containing $\mathrm{ZnO}$ nanoparticles were found only $1.4 \%$ and $1.7 \%$ for warp and weft directions respectively, lower than that of fabric without $\mathrm{ZnO}$ nanoparticles with $24.0 \%$ and $24.9 \%$ of respective reduction in warp and weft directions.
\end{abstract}

Keywords: binder, cotton fabric, ZnO nanoparticle, stabilizer, ultraviolet.

\section{PENDAHULUAN}

Kemajuan dalam teknologi material maju saat ini meningkat secara intensif dalam berbagai bidang aplikasi termasuk tekstil, sehingga memungkinkan pengembangan tekstil fungsional sebagai aspek lain dari tekstil konvensional sandang. Salah satu jenis tekstil fungsional yang saat ini banyak dikembangkan diantaranya adalah 
tekstil anti ultraviolet (UV). Radiasi sinar UV dapat menyebabkan berbagai efek negatif berupa kerusakan/dekomposisi pada material dan kesehatan kulit manusia, apabila tidak dilindungi. ${ }^{1}$ Peningkatan efek rumah kaca dan fenomena penipisan lapisan ozon yang semakin intensif menyebabkan jumlah total radiasi UV yang mencapai permukaan bumi meningkat tahun demi tahun., ${ }^{2,3}$ Proteksi kesehatan dan material terhadap efek negatif UV merupakan topik penelitian yang sangat potensial karena dapat diaplikasikan dalam berbagai bidang seperti medis, otomotif, konstruksi sipil/arsitektur, comfort fashion dan sebagainya.

Salah satu aplikasi tekstil fungsional untuk proteksi terhadap UV adalah material atap anti-UV. Bahan tekstil dapat bekerja dengan baik dalam fungsi proteksi anti-UV karena mengandung bahan aktif dengan karakteristik daya serap (absorpsi) UV yang optimum dengan metode immobilisasi yang sesuai pada permukaan tekstil. Absorber UV dapat berupa senyawa organik atau anorganik tak berwarna dengan daya absorpsi yang kuat pada rentang panjang gelombang UV $290-360 \mathrm{~nm}^{4}$ Beberapa penelitian sebelumnya mengenai kain anti-UV menyebutkan penggunaan senyawa polimer organik (benzotriazol, fenil triazin, dsb.) sebagai absorber UV. ${ }^{5,6}$ Dalam perkembangannya, absorber UV anorganik lebih banyak digunakan dengan beberapa kelebihan dibanding absorber organik, antara lain : tahan sinar dan stabilitas yang baik, serta efek proteksi UV yang jauh lebih lama. ${ }^{7,8} \mathrm{TiO}_{2}, \mathrm{CeO}_{2}$ dan $\mathrm{ZnO}$ adalah absorber yang paling banyak digunakan dalam studi proteksi radiasi UV.,10 Immobilisasi absorber UV pada berbagai jenis kain dalam penelitian sebelumnya telah berhasil dilakukan dengan mengaplikasikan beberapa metode antara lain: spinning, coating, padding dsb. ${ }^{5,11,12}$

Pengembangan kain atap anti-UV masih memerlukan penelitian lanjutan untuk meningkatkan kemampuan proteksi anti-UV dan feasibilitas dalam aplikasinya. Salah satu upaya untuk meningkatkan performa anti-UV adalah melalui teknologi nanomaterial dan pengembangan metode immobilisasi absorber UV yang sesuai pada kain. Penggunaan metode padding dengan proses pad-dry-cure diperkirakan akan sesuai untuk immobilisasi nanopartikel $\mathrm{ZnO}$ pada kain kanvas kapas. Dalam penelitian ini dipelajari metode preparasi suspensi nanopartikel $\mathrm{ZnO}$ dan teknik immobilisasi nanopartikel pada kain kanvas kapas untuk aplikasi atap anti-UV dengan proses pad-drycure.

\section{METODE}

\section{Bahan dan peralatan penelitian}

Bahan yang digunakan dalam penelitian ini antara lain: kain tenun kanvas bahan kapas gramasi $300 \mathrm{gram} / \mathrm{m}^{2}$ (Kanvas Mulia), kanji polyvinyl
alcohol/PVA teknis (Brataco), nanopartikel $\mathrm{ZnO}$ (Nanocenter Serpong), binder resin akrilat Rucocoat ACR 660-N (Rudolph), dan air demineralisasi (Brataco). Peralatan yang digunakan antara lain: mesin pad-dry-cure (Werner Mathis AG), magnetic stirrer, sonikator, oven dan buret tetes.

\section{Stabilisasi larutan suspensi nanopartikel}

Pada tahap awal dilakukan percobaan stabilisasi larutan suspensi nanopartikel melalui variasi konsentrasi poly vinyl alcohol (PVA) sebagai stabilizing agent pada larutan suspensi. Komposisi yang digunakan adalah 1\% $\mathrm{ZnO}, 3 \%$ resin akrilat dan PVA dengan variasi 2\%; 4\%; 6\%; $8 \%$; dan $10 \%$. Pembuatan larutan untuk menentukan konsentrasi PVA optimum diawali dengan memanaskan $25 \mathrm{~mL}$ air demineralisasi dalam 5 buah gelas beker $50 \mathrm{~mL}$, lalu tambahkan PVA dengan variasi $1 ; 2 ; 3 ; 4 ; 5$ gram dalam kondisi pengadukan cepat. Setelah larut, tambahkan kembali $25 \mathrm{~mL}$ air demineralisasi dalam tiap gelas beker, kemudian didinginkan hingga mencapai temperatur ruangan. Dalam tiap larutan dengan variasi konsentrasi PVA, tambahkan 0,5 g ZnO dan $2 \mathrm{~mL}$ resin akrilat, sambil diaduk cepat selama 15 menit kemudian didiamkan selama 24 jam. Seluruh variasi diaduk cepat menggunakan magnetic stirrer selama 60 menit. Pengendapan nanopartikel ZnO selama 24 jam diamati secara visual.

\section{Preparasi suspensi nanopartikel ZnO dengan variasi konsentrasi binder}

Pembuatan larutan suspensi nanopartikel $\mathrm{ZnO}$ untuk persiapan proses pad-dry-cure dilakukan dengan menggunakan konsentrasi PVA optimum berdasarkan percobaan sebelumnya, konsentrasi $\mathrm{ZnO} 1 \%$, dan variasi konsentrasi binder akrilat pada nilai 1\%; 3\%; 5\%. Pembuatan larutan diawali dengan memanaskan $500 \mathrm{~mL}$ air demineralisasi dalam 3 buah gelas beker $1000 \mathrm{~mL}$, lalu tambahkan 100 gram PVA dalam kondisi pengadukan cepat. Setelah larut, kemudian didinginkan hingga mencapai temperatur ruangan. Dalam tiap gelas beker tambahkan $10 \mathrm{~g} \mathrm{ZnO}$ dan variasi konsentrasi resin akrilat $10 \mathrm{~mL}$; $30 \mathrm{~mL}$ dan $50 \mathrm{~mL}$ sambil diaduk cepat selama 15 menit. Air demineralisasi ditambahkan ke dalam tiap gelas beker hingga volume akhir $1 \mathrm{~L}$.

\section{Proses pad-dry-cure}

Immobilisasi nanopartikel $\mathrm{ZnO}$ pada sampel kain dilakukan melalui proses pad-dry-cure dengan bantuan zat pengikat (binder). Percobaan pad-drycure dilakukan dengan menggunakan larutan suspensi yang telah dipersiapkan dengan memvariasikan konsentrasi binder akrilat (1\%; $3 \%$; $5 \%)$.

Tahap awal proses pad-dry-cure dimulai dengan menyiapkan sampel kain dengan ukuran 40 
cm x $32 \mathrm{~cm}$. Kain dicuci terlebih dahulu menggunakan sabun non-ionik kemudian dikeringkan. Selanjutnya kain dipadding sebanyak 3 kali pada larutan suspensi nanopartikel dan diperas hingga wet pick-up $80 \%$. Kain yang telah dipadding kemudian dikeringkan pada temperatur $110{ }^{\circ} \mathrm{C}$ selama 5 menit dan dilanjutkan dengan proses curing pada temperatur $150^{\circ} \mathrm{C}$ selama 3 menit. Kain yang telah melalui proses dibiarkan pada temperatur ruang selama 2 jam, kemudian disonikasi selama 30 menit untuk melepaskan nanopartikel $\mathrm{ZnO}$ yang tidak melekat sempurna pada permukaan kain.

\section{Pengujian dan karakterisasi}

Evaluasi karakteristik dan morfologi kain tenun kanvas anti UV menggunakan instrumen scanning electron microscopy/SEM (JEOL, JSM 6510, Japan). Perubahan sifat kain akibat pengaruh hujan dievaluasi dengan uji siram air hujan Bundesmann, mengikuti standard SNI ISO 9865:2013. Pengaruh radiasi UV terhadap kualitas kain dievaluasi dengan pemaparan sinar UV menggunakan fotoreaktor berpenutup yang dilengkapi lampu UV-C 3 x 15 watt (Vilbert Lourmat) dengan panjang gelombang $254 \mathrm{~nm}$. Ketahanan kain dievaluasi melalui pengujian kekuatan tarik dan mulur (standar SNI 0276:2009).

\section{HASIL DAN PEMBAHASAN}

\section{Optimasi konsentrasi stabilizer}

Hasil pengamatan terhadap larutan dengan variasi konsentrasi PVA dan variabel tetap konsentrasi nanopartikel ZnO dan binder akrilat, diperlihatkan pada Tabel 1. Percobaan ini bertujuan untuk memperoleh larutan suspensi nanopartikel ZnO-stabilizer-binder yang stabil dengan menganalisis pengaruh variasi konsentrasi stabilizer
(PVA). Berdasarkan pengamatan selama 24 jam terlihat bahwa pada penggunaan konsentrasi PVA 8\% kondisi larutan masih cukup stabil, namun pada pengamatan 48 jam terjadi endapan. Pada konsentrasi PVA 10\% kondisi larutan terlihat masih stabil pada pengamatan setelah 48 jam, sehingga konsentrasi PVA 10\% dianggap sebagai nilai optimum untuk percobaan selanjutnya.

\section{Evaluasi variasi konsentrasi binder dan nanopartikel ZnO}

Evaluasi pengaruh variasi konsentrasi binder dan nanopartikel $\mathrm{ZnO}$ dalam larutan suspensi terhadap morfologi kain setelah immobilisasi dilakukan melalui pengambilan citra SEM seperti ditunjukkan pada Gambar 1 dan 2. Variasi konsentrasi binder akrilat dilakukan pada $1 \%$ dan dan 5\%, dengan variabel tetap konsentrasi nanopartikel ZnO (1\%) dan PVA (10\%). Hasil pengamatan citra SEM pada Gambar 1 menunjukkan bahwa pada konsentrasi binder yang lebih tinggi, nanopartikel terperangkap dalam senyawa binder yang berikatan dengan serat kain. Hal ini memungkinkan terjadinya perlekatan nanopartikel yang kuat pada matriks kain yang akan dievaluasi lebih lanjut melalui uji siram hujan.

Hasil pengamatan terhadap variasi konsentrasi nanopartikel $\mathrm{ZnO}$ (1\% dan 5\%) dengan variabel tetap konsentrasi binder (5\%) dan stabilizer (10\%) diperlihatkan pada Gambar 2. Citra SEM pada Gambar 2 menunjukkan adanya peningkatan distribusi nanopartikel pada permukaan serat seiring dengan meningkatnya konsentrasi nanopartikel. Citra SEM memperlihatkan nanopartikel cenderung mengalami aglomerasi pada permukaan serat, namun demikian nanopartikel masih terdistribusi cukup merata.

Tabel 1. Perbandingan konsentrasi nanopartikel $\mathrm{ZnO}$ /stabilizer /binder dalam larutan dengan variasi stabilizer (PVA)

\begin{tabular}{ccccccccc}
\hline & \multicolumn{9}{c}{ Perbandingan konsentrasi (\%) } & \multicolumn{7}{c}{ Hasil pengamatan endapan (jam) } \\
\cline { 2 - 8 } Variasi & $\begin{array}{c}\text { Nanopartikel } \\
\text { ZnO }\end{array}$ & PVA & Akrilat & $\mathbf{1}$ & $\mathbf{6}$ & $\mathbf{2 4}$ & $\mathbf{4 8}$ \\
\hline 1 & 1 & 2 & 3 & $\sqrt{ }$ & $\sqrt{ }$ & $\sqrt{ }$ & $\sqrt{ }$ \\
2 & 1 & 4 & 3 & - & $\sqrt{ }$ & $\sqrt{ }$ & $\sqrt{ }$ \\
3 & 1 & 5 & 3 & - & - & $\sqrt{ }$ & $\sqrt{ }$ \\
4 & 1 & 8 & 3 & - & - & - & $\sqrt{ }$ \\
5 & 1 & 10 & 3 & - & - & - & - \\
\hline
\end{tabular}

$\sqrt{\text { : tampak endapan }}$

Nanopartikel memiliki berbagai keuntungan seperti ukuran partikel yang kecil, luas permukaan spesifik yang besar, magnetisme yang kuat, fotokatalitik, sifat absorpsi khusus seperti pada radiasi UV, aktivitas permukaan yang besar, performa transfer panas yang baik dan sifat suspensi cair yang stabil. ${ }^{8}$ Dengan kelebihan tersebut nanopartikel anorganik dapat menunjukkan sifat proteksi UV yang lebih baik dari mikropartikel. Beberapa referensi menyebutkan nanopartikel $\mathrm{ZnO}$ komersial umumnya bermasalah pada aglomerasi yang dapat menyebabkan kesulitan 
dispersi uniform nanopartikel pada media finishing dan penurunan durabilitas. ${ }^{1,13}$ Upaya stabilisasi suspensi dan metode immobilisasi padding yang dilakukan pada penelitian ini merupakan salah satu langkah preventif untuk mengurangi semaksimal mungkin kemungkinan aglomerasi nanopartikel pada permukaan kain.
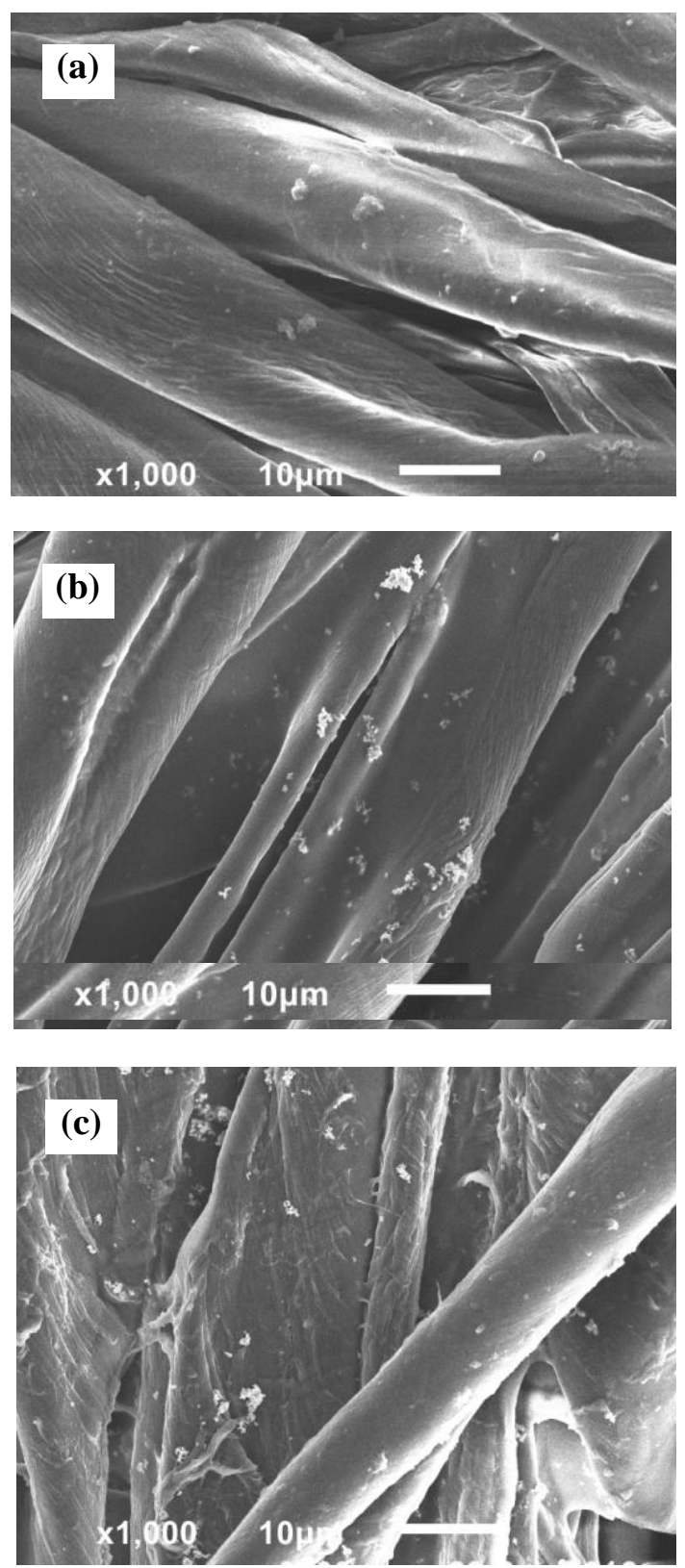

Gambar 1. Citra SEM kain kanvas dengan variasi konsentrasi binder: a) Tanpa binder; b) Binder 1\%; c) Binder 5\% (Pembesaran 1000x).

\section{Evaluasi immobilisasi nanopartikel pada kain}

Kekuatan perlekatan nanopartikel $\mathrm{ZnO}$ pada kain kanvas berdasarkan variasi konsentrasi binder dievaluasi melalui uji siram air hujan. Tabel 2 memperlihatkan hasil uji siram air hujan dengan metode Bundesmann. Hasil uji siram air hujan menunjukkan bahwa kemampuan daya tolak air berbanding lurus dengan konsentrasi binder. Semakin tinggi konsentrasi binder, daya tolak kain terhadap air hujan semakin meningkat.
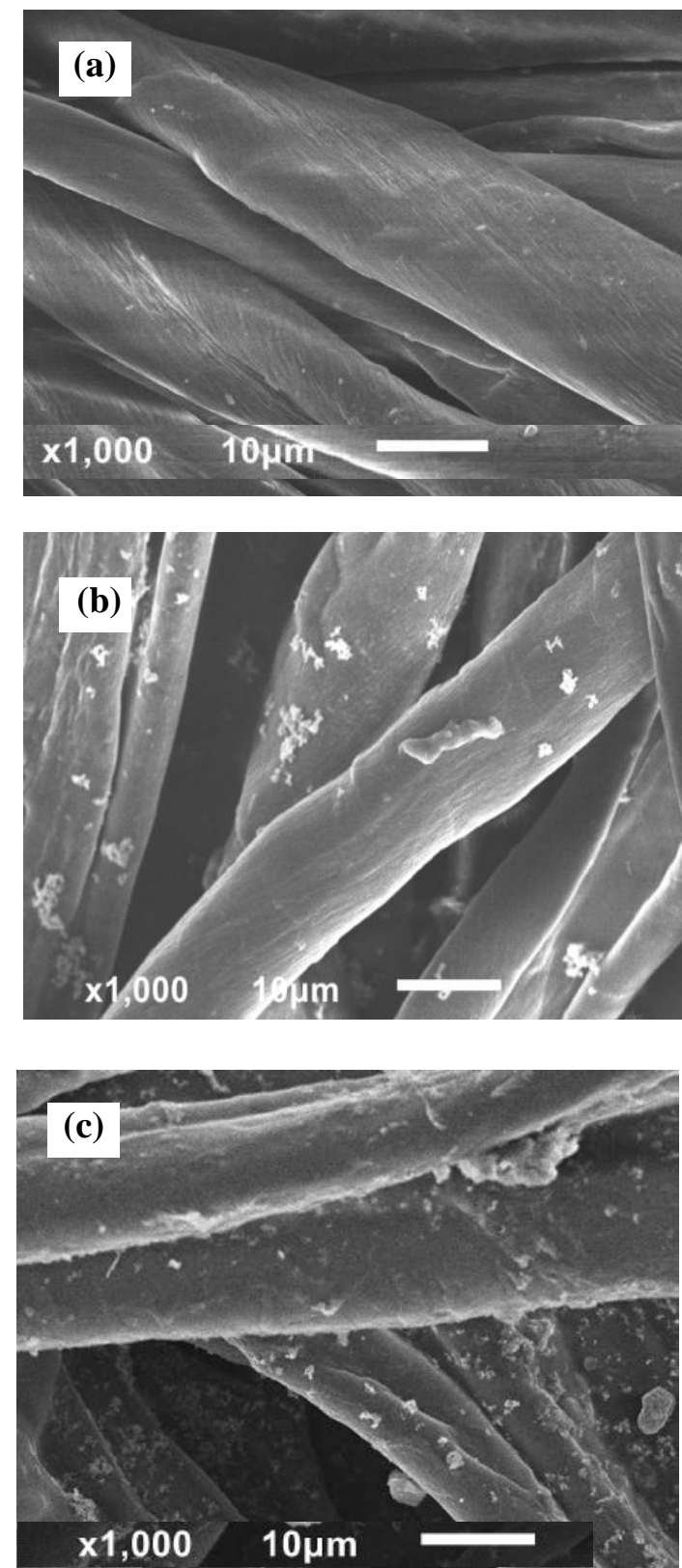

Gambar 2. Citra SEM kain kanvas dengan variasi konsentrasi nanopartikel ZnO: a) Tanpa nanopartikel; b) Nano-partikel 1\%; c) Nanopartikel 

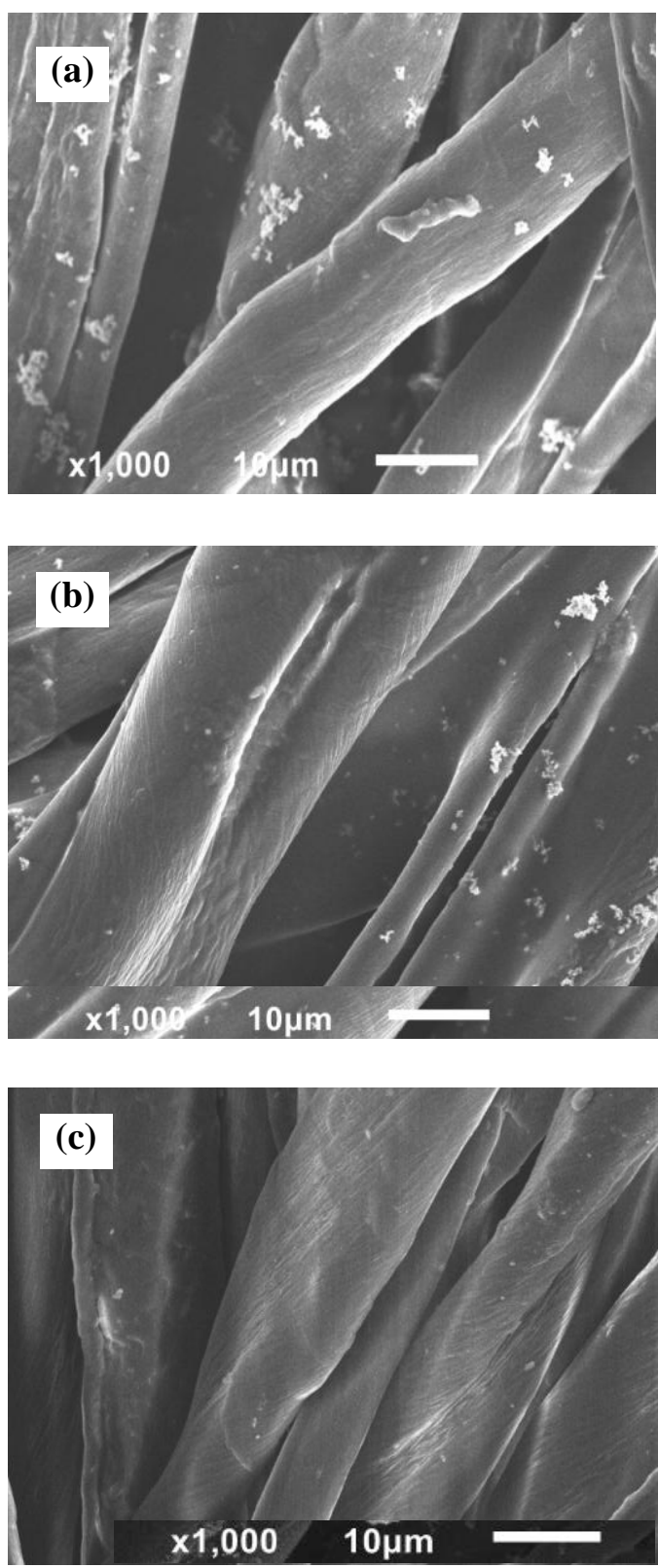

Gambar 3. Citra SEM kain kanvas dengan konsentrasi binder 1\%: a) Sebelum; b) Uji siram hujan 10 menit; c) Uji siram hujan 60 menit. (Pembesaran 1000x).

Peningkatan konsentrasi binder hingga 5\% pada komposisi padding kain kanvas dapat menurunkan tingkat perembesan dan penyerapan air pada kain. Konsentrasi binder 5\% ternyata hanya mencapai grade daya tolak air 1 , sehingga masih memerlukan proses lebih lanjut untuk dapat mencapai grade daya tolak air 5 (water repellent). Namun demikian, evaluasi variasi konsentrasi binder dalam penelitian ini hanya bertujuan untuk melihat pengaruhnya terhadap immobilisasi nanopartikel ZnO pada permukaan kain.
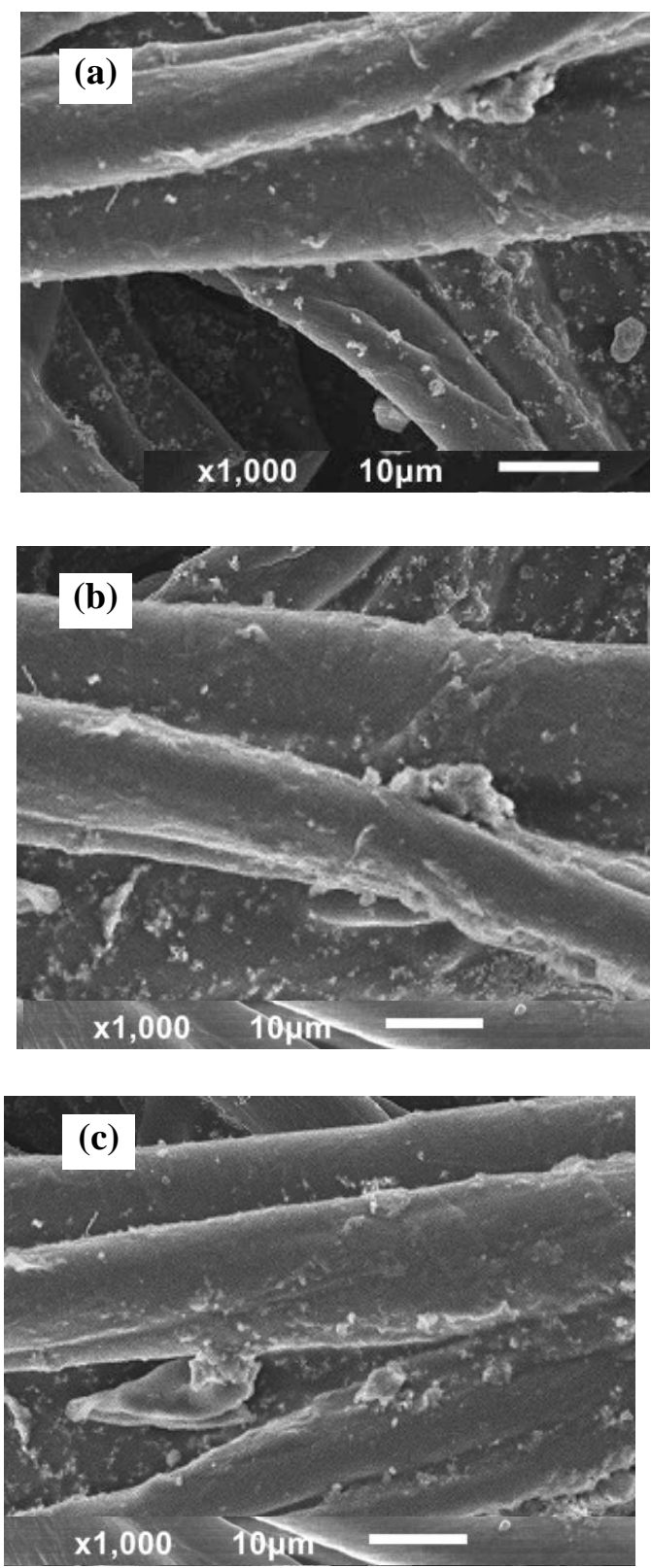

Gambar 4. Citra SEM kain kanvas dengan konsentrasi binder 5\%: a) Sebelum; b) Uji siram hujan 10 menit; c) Uji siram hujan 60 menit. (Pembesaran 1000x)

Kekuatan perlekatan nanopartikel $\mathrm{ZnO}$ pada kain kanvas berdasarkan variasi konsentrasi binder melalui uji siram air hujan lebih jauh dievaluasi melalui citra SEM. Gambar 3 dan 4 memperlihatkan gradasi permukaan kain yang telah dipadding nanopartikel $\mathrm{ZnO}$ 5\% dengan variasi konsentrasi binder, sebelum dan setelah uji siram hujan selama 10 menit dan 60 menit. Pada konsentrasi binder 1\%, nanopartikel $\mathrm{ZnO}$ masih terlihat pada uji siram hujan 10 menit, namun tidak dapat mempertahankan perlekatan terhadap uji siram hujan 60 menit. 
Tabel 2. Hasil uji daya tolak air melalui uji siram air hujan dengan variasi konsentrasi binder

\begin{tabular}{llccc}
\hline No & Konsentrasi binder & $\begin{array}{c}\text { Perembesan } \\
(\mathbf{m L})\end{array}$ & $\begin{array}{c}\text { Penyerapan } \\
(\mathbf{\%})\end{array}$ & Grade daya tolak air* \\
\hline 1 & Tanpa binder & $152 \mathrm{~mL}$ & 81,32 & 1 \\
2 & Binder 1\% & $17 \mathrm{~mL}$ & 52,74 & 1 \\
3 & Binder 3\% & $16 \mathrm{~mL}$ & 49,47 & 1 \\
4 & Binder 5\% & $8 \mathrm{~mL}$ & 45,49 & 1 \\
\hline
\end{tabular}

*Grade 1: seluruh permukaan kain basah

Pada penggunaan konsentrasi binder 5\%, nanopartikel masih terlihat melekat dengan baik hingga uji siram hujan selama 60 menit. Keberadaan binder ternyata cukup signifikan dalam mempengaruhi perlekatan nanopartikel pada permukaan kain. Konsentrasi binder yang rendah menyebabkan nanopartikel tidak melekat cukup baik sehingga masih dapat lepas setelah uji siram hujan. Konsentrasi binder lebih tinggi memungkinkan terbentuknya ikatan nanopartikel dengan matriks kain sehingga dapat bertahan terhadap uji siram hujan.

\section{Evaluasi performa kain terhadap pengaruh sinar UV}

Pengaruh radiasi UV terhadap kain kanvas kapas terimmobilisasi nanopartikel $\mathrm{ZnO}$ dievaluasi melalui pengujian kekuatan tarik dan mulur kain. Pemaparan radiasi sinar UV dilakukan pada kain blanko (tanpa perlakuan) dan kain dengan perlakuan (immobilisasi nanopartikel ZnO). Kain terimmobilisasi $\mathrm{ZnO}$ menggunakan perlakuan komposisi: nanopartikel 5\%, binder $5 \%$ dan stabilizer $10 \%$. Percobaan irradiasi UV dilakukan dengan fungsi waktu pemaparan UV $1-5$ jam. Hasil uji kekuatan tarik dan mulur pada ketiga sampel kain ditunjukkan pada Gambar 5 dan 6.

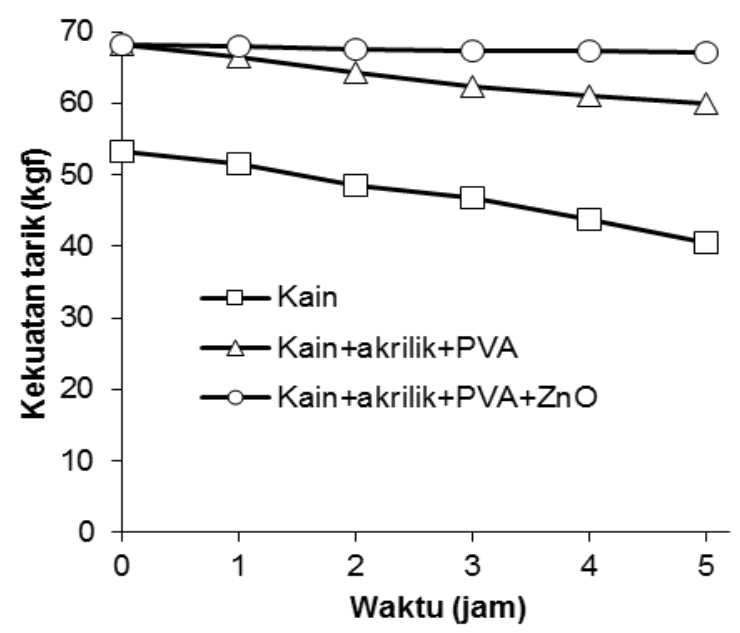

(a)
Hasil uji kekuatan tarik (Gambar 5) memperlihatkan adanya penurunan kekuatan tarik sampel kain kanvas arah lusi dan pakan seiring peningkatan waktu irradiasi UV. Setelah pemaparan radiasi UV selama 5 jam, kain blanko mengalami penurunan kekuatan tarik pada arah lusi dan pakan masing-masing sebesar $24,0 \%$ dan $24,9 \%$. Kain blanko dengan penambahan binder dan stabilizer mengalami penurunan kekuatan tarik pada arah lusi dan pakan masing-masing sebesar $11,9 \%$ dan $14,4 \%$. Sementara, kain terimmobilisasi nanopartikel $\mathrm{ZnO}$ mengalami penurunan kekuatan tarik pada arah lusi dan pakan masing-masing sebesar $1,4 \%$ dan $1,7 \%$.

Hasil uji mulur juga memperlihatkan penurunan persentase mulur pada sampel kain kanvas seiring peningkatan waktu radiasi UV (Gambar 6). Kain blanko mengalami penurunan persentase mulur masing-masing sebesar $27,1 \%$ dan 27,8\% pada arah lusi dan pakan setelah pemaparan radiasi UV selama 5 jam. Kain blanko dengan penambahan binder dan stabilizer mengalami penurunan persentase mulur masing-masing sebesar $16,3 \%$ dan 15,9\%. Dengan durasi yang sama, sampel kain terimmobilisasi nanopartikel $\mathrm{ZnO}$ mengalami penurunan mulur pada arah lusi dan pakan masing-masing hanya sebesar $1,8 \%$ dan $0,8 \%$.

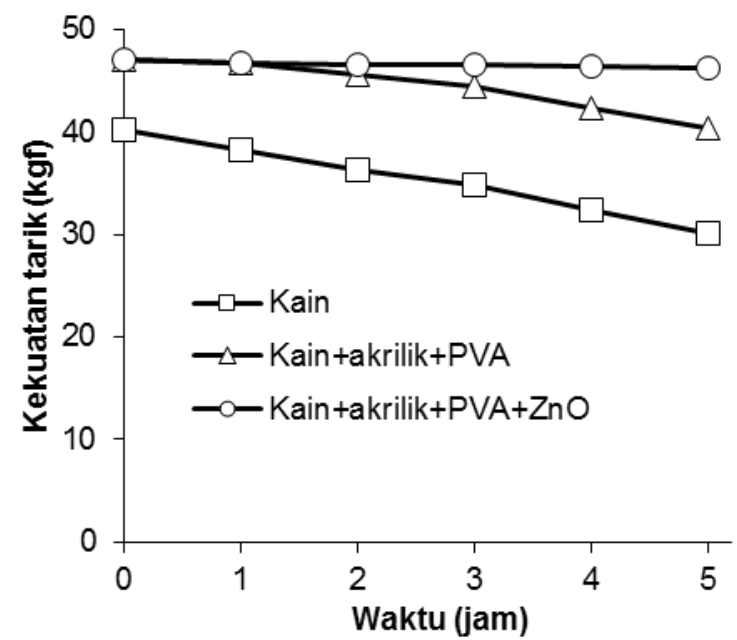

(b)

Gambar 5. Grafik uji kekuatan tarik kain kanvas: a) arah lusi; b) arah pakan. 


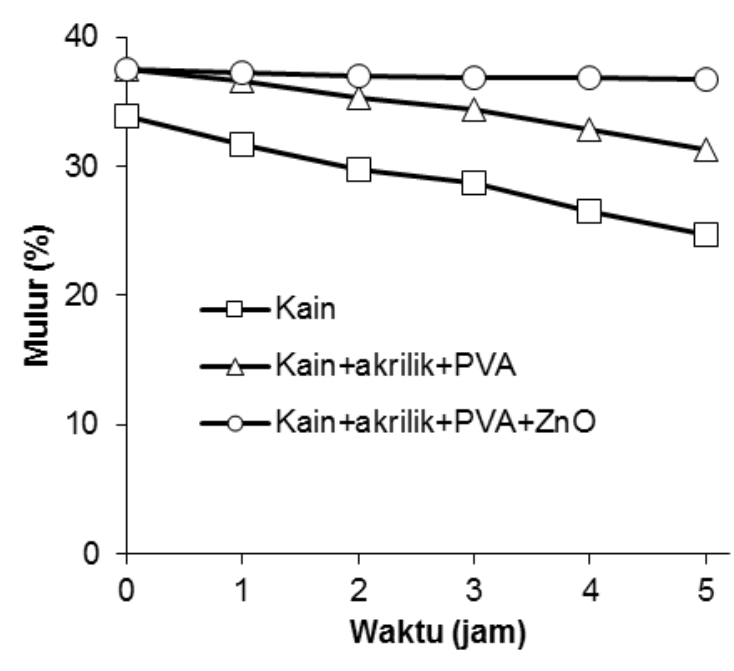

(a)

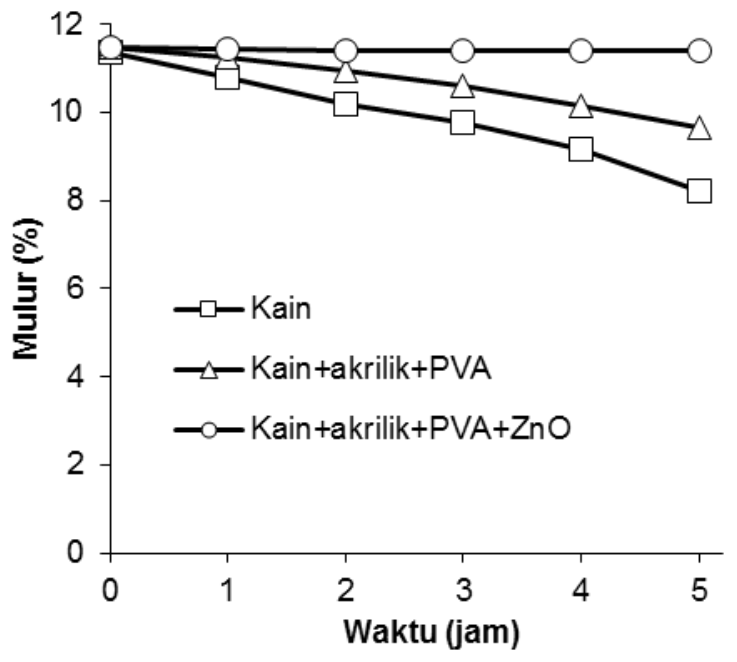

(b)

Gambar 6. Grafik uji mulur kain kanvas: a) arah lusi; b) arah pakan.

Hasil penelitian ini sejalan dengan studi lain yang mempelajari pengaruh radiasi UV pada sinar matahari terhadap sifat fisik kain menyebutkan bahwa penambahan proteksi anti-UV dapat menghambat pengurangan kekuatan tarik. Dilaporkan bahwa tanpa adanya sifat anti UV, terjadi kehilangan kekuatan tarik pada nilon, wol, kapas dan poliester sebanyak masing-masing $100 \%$, $23 \%$, 34\% dan $44 \%$, setelah pemaparan selama 30 hari. ${ }^{5}$ Proteksi anti UV pada kain secara signifikan dapat berkontribusi untuk mempertahankan kualitas dan usia material tekstil.

Radiasi UV adalah satu dari penyebab utama degradasi pada material tekstil yang disebabkan oleh eksitasi dari beberapa bagian dari molekul polimer. Porositas optik dan rasio volume permukaan yang tinggi dari struktur kain tenun membatasi kemampuannya untuk menyediakan proteksi terhadap radiasi UV. ${ }^{\mathbf{1}}$ Penetrasi radiasi UV pada kain kapas menyebabkan fotooksidasi dan menyebabkan berkurangnya elastisitas, kekuatan tarik dan peningkatan derajat kristalinitas. Hasil penelitian ini menunjukkan bahwa keberadaan binder dan stabilizer pada kain mampu menghambat penetrasi radiasi UV hingga dapat mempertahankan ketahanan kain hingga batas tertentu. Namun demikian, nanopartikel $\mathrm{ZnO}$ memiliki sebagai absorber UV memiliki mekanisme yang spesifik dalam mempertahankan struktur serat lusi dan pakan dari kerusakan akibat degradasi UV. Dalam penelitian ini, immobilisasi nanopartikel $\mathrm{ZnO}$ memperlihatkan pengaruh lebih signifikan dalam meningkatkan ketahanan kain terhadap radiasi UV.

Nanopartikel ZnO sebagai absorber UV berperan dalam memproteksi bahan terhadap radiasi
UV melalui beberapa skema antara lain menghilangkan intensitas UV, atenuasi UV dan penyebaran sinar UV. ${ }^{6}$ Penghilangan intensitas radiasi UV terjadi melalui konversi energi cahaya menjadi bentuk lain seperti panas melalui proses eksitasi elektron dari pita valensi ke pita konduksi. Atenuasi radiasi UV dapat terjadi melalui absorpsi band gap dan penyebaran (scattering) sinar UV. ${ }^{14}$

Ketahanan kain terhadap efek sinar UV yang cukup signifikan yang dihasilkan melalui penggunaan nanopartikel $\mathrm{ZnO}$ dalam penelitian ini dapat pula disebabkan beberapa karakteristik fisiknya. Salah satu kendala aplikasi absorber UV anorganik adalah terjadinya aglomerasi sehingga mengurangi efektivitasnya. Dibanding senyawa oksida lain, nanopartikel $\mathrm{ZnO}$ memiliki distribusi ukuran partikel yang lebih sempit $(20-40 \mathrm{~nm})$ dan agregasi minimal sehingga memungkinkan distribusi uniform yang menghasilkan tingkat proteksi UV yang lebih baik. ${ }^{13}$ Selain itu, ZnO memiliki spektrum absorpsi UV yang lebar, sementara tipikal absorber UV anorganik lain memiliki puncak absorpsi hanya pada panjang gelombang tertentu. 15,16,17 Dalam penggunaan jangka panjang $\mathrm{ZnO}$ memberikan beberapa keuntungan lain yaitu karakteristik antifungal dan antistatik, sehingga memungkinkan proteksi lebih baik pada material kain. ${ }^{\mathbf{1 8 , 1 9}}$

\section{KESIMPULAN}

Hasil penelitian immobilisasi nanopartikel $\mathrm{ZnO}$ dengan metode padding menunjukkan bahwa larutan padding yang stabil dapat diperoleh dengan penggunaan konsentrasi stabilizer PVA $10 \%$. Perlekatan nanopartikel $\mathrm{ZnO}$ pada kain kapas 
semakin baik seiring peningkatan penggunaan konsentrasi binder, dimana penggunaan konsentrasi binder $5 \%$ terlihat lebih baik dibandingkan konsentrasi binder lebih rendah. Immobilisasi nanopartikel ZnO dengan konsentrasi 5\% cukup efektif dalam mempertahankan penurunan kekuatan tarik dan mulur kain kanvas kapas terhadap irradiasi UV selama 5 jam. Tanpa immobilisasi nanopartikel $\mathrm{ZnO}$ beserta binder dan stabilizer, irradiasi UV menyebabkan penurunan kekuatan tarik kain kanvas arah lusi dan pakan masing-masing sebesar $24,0 \%$ dan 24,9\%, serta penurunan mulur arah lusi dan pakan masing-masing sebesar $27,1 \%$ dan 27,8\%. Dengan immobilisasi nanopartikel $\mathrm{ZnO}$, penurunan kekuatan tarik arah lusi dan pakan masing-masing hanya sebesar 1,4\% dan 1,7\%, sedangkan penurunan mulur arah lusi dan pakan masing-masing hanya sebesar $1,8 \%$ dan $0,8 \%$.

\section{UCAPAN TERIMAKASIH}

Penelitian ini terlaksana dengan bantuan anggaran penelitian DIPA Balai Besar Tekstil tahun 2016.

\section{PUSTAKA}

1. Kim, Y.K. Ultraviolet protection finishes for textiles. Functional finishes for textile. $1^{\text {st }} \mathrm{ed}$. Elsevier (2015).

2. WHO, Solar ultraviolet radiation: global burden of disease from solar ultraviolet radiation, Environmental burden of disease series 13 (2006)

3. Dutra, E.A., Oliveira, D.A., Hackmann, E.R., dan Santoro. M.I. Determination of sun protection factor (SPF) of sunscreens by ultraviolet spectrophotometry. Brazilian Journal of Pharmaceutical Sciences 40(3), 381 - 385 (2004).

4. Selishchev, D.S., Karaseva, I.P., Uvaev, V.V. Kozlov, D.V., dan Parmon, V.N. Effect of preparation method of functionalized textile materials on their photocatalytic activity and stability under UV irradiation. Chemical Engineering Journal 224, 114-120 (2013).

5. Li, H., Deng H. dan Zhao, J. Performance research of polyester fabric treated by nano titanium dioxide (nano- $\mathrm{TiO}_{2}$ ) anti-ultraviolet finishing. International Journal of Chemistry 1(1), 57 - 62 (2009).

6. Saravanan, D. Ultraviolet protection textile materials. AUTEX Research Journal 7(1), 53 62 (2007).

7. Radetic, M. Review: Functionalization of textile materials with $\mathrm{TiO}_{2}$ nanoparticles.
Journal of Photochemistry and Photobiology C: Photochemistry Reviews 16, 62- 76 (2013).

8. Fakin, D., Veronovski, N., Ojstrsek, A., Bozic, M. Synthesis of $\mathrm{TiO}_{2}-\mathrm{SiO}_{2}$ colloid and its performance in reactive dyeing of cotton fabrics. Carbohydrate Polymers 88, 992- 1001. (2012).

9. Zayat, M., Garcia-Parejo, P. dan Levy, D. Preventing UV-light damage on light sensitive materials using a highly protective UVabsorbing coating, Chemical Society Reviews 36, $1270-1281$ (2007).

10. Lu, Z., Mao, C., Meng, M., Liu, S., Tian, Y., $\mathrm{Yu}$, L., et al. Fabrication of $\mathrm{CeO}_{2}$ Nanoparticlemodified Silk for UV Protection and Antibacterial Applications. Journal Colloid Interface Science 435, 8-14 (2014).

11. Dastjerdi, R., Montazera, M., dan Shahsavan, S. A novel technique for producing durable multifunctional textiles using nanocomposite coating. Colloids and Surfaces B: Biointerfaces 81, 32-41 (2010).

12. Ibrahim, N.A., El-Zairy, E.M.R., Abdalla, W.A., dan Khalil, H.M. Combined UVprotecting and reactive printing of Cellulosic/wool blends, Carbohydrate Polymers 92, 1386- 1394 (2013).

13. Tsuzuki, $\mathrm{T}$. dan Wang, $\mathrm{X}$. Nanoparticle coatings for $U V$ protective textiles, RJTA, 14 (2), 9 - 21 (2010).

14. Kasap, S.O. Electronic materials and Devices (3rd ed.), McGraw-Hill New York (2006).

15. Scalia, S., Tursilli, R., Bianchi, A., Lo-Nostro, P., Bocci, E., Ridi, F., et al. Incorporation of the sunscreen agent, octyl methocycinnamate in a cellulosic fabric grafted with bcyclodextrin. International Journal of Pharmaceutics 308, 155-159 (2006).

16. Mahltig, B., Böttcher, H., Rauch, K., Dieckmann, U., Nitsche, R. dan Fritz, T. Optimized UV protecting coatings by combination of organic and inorganic UV absorbers, Thin Solid Films 485(1-2), 108-114 (2005).

17. Innes, B., Tsuzuki, T., Dawkins, H., Dunlop, J., Trotter, G., Nearn, M.R., et al. Nanotechnology and the cosmetic chemist. Cosmetics, aerosols and toiletries in Australia, 15(10-12), 21-24. (2002).

18. Sawaji, J. dan Yoshikawa, T. Quantitative evaluation of antifungal activity of metallic oxide powders ( $\mathrm{MgO}, \mathrm{CaO}$ and $\mathrm{ZnO}$ ) by an indirect conductimetric assay, Journal of Applied Microbiology 96(4), 803-809 (2004). 
Immobilisasi Nanopartikel ZnO pada Kain Atap Kapas dan Evaluasi Ketahanannya terhadap Ultraviolet (Doni Sugiyana, dkk.)

19. Yadollahia, Gholamalia, I., Namazia, H., dan Aghazadeh, M. Synthesis and characterization of antibacterial carboxymethylcellulose/ZnO nanocomposite hydrogels, International Journal of Biological Macromolecules 74, 136-141(2015). 
Arena Tekstil Vol. 32 No. 1, 2017: 25-34 